\title{
Faktor-Faktor yang Berhubungan dengan Kejadian BBLR di Wilayah Kerja Puskesmas Peudada Kabupaten Bireuen
}

\author{
The Factors Associated with LBW Occurrence in Peudada health working area \\ centre Kabupaten Bireuen \\ Minda Septiani ${ }^{1}$, Maria Ulfa ${ }^{2}$ \\ ${ }^{1,2}$ Akademi Kebidanan Munawarah, Jalan Sultan Iskandar Muda, No. 18 Kota Juang, Bireuen \\ *Korespondensi Penulis: mindaseptiani88@gmail.com
}

\begin{abstract}
Abstrak
World Health Organization (WHO) menyatakan lebih dari 2/3 kematian neonatus disebabkan oleh BBLR yaitu berat badan lahir kurang dari 2500 gram. Berdasarkan data Dinas Kesehatan Kabupaten Bireuen pada tahun 2017 jumlah BBLR sebanyak 266 kasus dari 8.746 jumlah kelahiran bayi (3\%). Kasus BBLR tertinggi di Kabupaten Bireuen adalah di Kecamatan Peudada yaitu sebanyak 30 kasus dari 568 jumlah kelahiran hidup (5,2\%). Jenis penelitian adalah studi analitik dengan pendekatan case control. Populasi adalah seluruh ibu yang melahirkan bayi BBLR dan bukan BBLR di wilayah kerja Puskesmas Peudada. Sampel dalam penelitian ini adalah keseluruhan dari populasi yang berjumlah 30 kasus dan 30 kontrol. Data dianalisis secara univariat dan bivariat dengan menggunakan uji chi-Square pada taraf kepercayaan $95 \%$ ( $\mathrm{p}<0,05)$. Hasil penelitian menunjukkan variabel usia hamil berisiko berhubungan dengan kejadian BBLR dengan nilai $p$-value $=0,008$ dan $\mathrm{OR}=5,231$. Variabel paritas berhubungan dengan kejadian BBLR dengan nilai $p$-value $=0,034$ dan $\mathrm{OR}=3,755$. Variabel usia kehamilan berhubungan dengan kejadian BBLR dengan nilai $p$-value $=0,012$ dan $\mathrm{OR}=8,105$. Variabel kekurangan energi kronik berhubungan dengan kejadian BBLR dengan nilai $p$-value $=0,007$ dan $\mathrm{OR}=5,714$. Variabel kunjungan ANC berhubungan dengan kejadian BBLR dengan nilai $p$-value $=0,036$ dan $\mathrm{OR}=3,596$. Disarankan Kepada tenaga kesehatan dan Puskesmas Peudada, untuk memberikan pelayanan, pendidikan, penyuluhan dan menggalakkan program untuk mengatasi masalah yang terkait dengan kejadian BBLR.
\end{abstract}

Kata Kunci : Kejadian BBLR, Faktor Usia Hamil Berisiko, Paritas, Usia Kehamilan, Kekurangan Energi Kronik, Kunjungan ANC

\begin{abstract}
The World Health Organization (WHO) states more than 2/3 neonatal deaths are caused by $L B W$. Based on data from Bireuen District Health Office in 2016, the number of LBW was 266 cases from 8,746 the number of babies born (3\%). The highest case of BBLR in Kabupaten Bireuen was in Peudada sub-district from January to December 2017, which was 30 cases from 568 live births (5.2\%). The objectives of the study were to analyze the risk factors of pregnancy, parity, gestational age, KEK and antenatal care visits related to $L B W$ occurrence in the Working Area of Puskesmas Peudada of Bireuen Regency in 2018. The type of research was an analytic study with case control approach. The population were all mothers who give birth to LBW infants and not LBW in the work area of Puskesmas Peudada.
\end{abstract}


The sample in this study is the total of the population of 30 cases and 30 controls. Data were analyzed by using univariate and bivariate with chi-square test at 95\% confidence level ( $p$ $<0,05)$. The results showed that pregnancy risk variables were associated with $L B W$ incidence with $p$-value $=0.008$ and $O R=5,231, L B W$ incidence was higher at aged <20 years and $>35$ years than aged 20-35 years. Parity variable is related to the occurrence of $L B W$ with p-value $=0,034$ and $O R=3,755$, the incidence of $L B W$ is higher in mothers with parity $\geq 4$ people than mothers with parity $<4$ people. The variable of pregnancy aged was related to the occurrence of $L B W$ with $p$-value $=0,012$ and $O R=8,105$, the occurrence of $L B W$ was higher at gestational age $\geq 37$ weeks than gestational age $<37$ weeks. Chronic energy deficiency variable was related to the occurrence of $L B W$ with $p$-value $=0,007$ and $O R=5,714$, the incidence of $L B W$ was higher for mothers experiencing KEK than women who did not experience KEK. The variable of visit of ANC was related to the occurrence of $L B W$ with $p$-value $=0,036$ and $O R=3,596$, higher $L B W$ incidence in mothers with ANC visit $<4$ times than mothers with ANC visit $\geq 4$ times. It is suggested to the Health Department, health workers and also Puskesmas Peudada of Bireuen District to provide services, education, counseling and promoting programs to address problems related to LBW occurrences that can be caused by risk factors: pregnancy age at risk $<20$ years and $>35$ years, Parity $\geq 4$ people, Chronic energy shortage and ANC visit $<4$ times.

Keywords: LBW Occurrence, Risk of Pregnant Factor, Parity, Pregnancy Age, Chronic Energy Deficiency, Antenatal Care Visit

\section{PENDAHULUAN}

Angka Kematian Bayi (AKB) merupakan indikator pertama dalam menentukan derajat kesehatan anak. Selain itu, angka kematian bayi juga merupakan cerminan dari status kesehatan masyarakat. Sebagian besar penyebab kematian bayi dan balita adalah masalah yang terjadi pada bayi baru lahir/ neonatal (umur 0-28 hari). Masalah neonatal ini meliputi asfiksia (kesulitan bernafas saat lahir), Bayi Berat Lahir Rendah (BBLR) dan infeksi (Depkes, RI, 2011).

Semua angka kematian bayi dan anak hasil SDKI 2012 lebih rendah dari hasil SDKI 2007. Untuk periode lima tahun sebelum survei, angka kematian bayi hasil SDKI 2012 adalah 32 kematian per 1.000 kelahiran hidup dan kematian balita adalah 40 kematian per 1.000 kelahiran hidup. Sama dengan pola SDKI 2007, lebih dari tiga perempat dari semua kematian balita terjadi dalam tahun pertama kehidupan anak dan mayoritas kematian bayi terjadi pada periode neonatus (SDKI, 2012).

Menurut World Health Organization (WHO), pada tahun 2013 hampir semua (98\%) dari 5 juta kematian neonatal di negara berkembang atau berpenghasilan rendah. Lebih dari 2/3 kematian adalah BBLR yaitu berat badan lahir kurang dari 2500 gram. Prevalensi bayi berat lahir rendah (BBLR) diperkirakan $15 \%$ dari seluruh kelahiran di dunia dengan batasan 
3,3\% - $38 \%$ dan lebih sering terjadi di negara berkembang atau sosial ekonomi rendah. Data statistik menunjukkan $90 \%$ kejadian BBLR didapatkan di negara berkembang dan angka kematiannya 35 kali lebih tinggi dibanding pada bayi dengan berat lahir lebih dari 2500 gram (SDKI, 2014).

Bayi berat lahir rendah (BBLR) adalah bayi yang lahir dengan berat badan kurang dari 2.500 gram tanpa memandang masa kehamilan. Dahulu neonatus dengan berat badan lahir kurang dari 2.500 gram atau sama dengan 2.500 gram disebut premature. Sehingga lambat laun diketahui bahwa tingkat morbiditas dan mortalitas pada bayi tidak hanya bergantung pada berat badan saja, tetapi pada tingkat maturitas bayi itu sendiri (Proverawati, 2010).

Bayi BBLR banyak sekali risiko terjadi permasalahan pada sistem tubuh, karena kondisi tubuh yang tidak stabil. Kematian perinatal pada bayi BBLR adalah 8 kali lebih besar dari bayi normal. Prognosis akan lebih buruk bila berat badan semakin rendah, kematian sering disebabkan karena komplikasi neonatal seperti asfiksia, aspirasi pneumonia, perdarahan intracranial, infeksi, hipotermi dan hipoglikemia masih tinggi di Indonesia. Dengan kata lain, tingginya angka kematian tersebut disebabkan BBLR sangat rentan terhadap berbagai dengan gejala yang bervariasi. Indikator kesehatan suatu bangsa masih dilihat dari tinggi dan rendahnya angka kematian bayi, termasuk kematian bayi BBLR (Ridwan, 2014).

Hasil Riset Kesehatan Dasar (Riskesdas) tahun 2013 menyatakan bahwa persentase balita (0-59 bulan) dengan BBLR sebesar 10,2\%. Berdasarkan data Profil Kesehatan Indonesia tahun 2013 bahwa persentase BBLR tertinggi terdapat di Provinsi Sulawesi Tengah (16,8\%), Provinsi Papua (15,6\%), Provinsi Nusa Tenggara Timur (15,5\%), dan terendah di Provinsi Sulawesi Utara (8,0\%), Provinsi Sumatra Barat (7,3\%), dan Provinsi Sumatra Utara (7,2\%) (Kemenkes RI, 2014).

Faktor-faktor yang berhubungan dengan BBLR antara lain faktor ibu meliputi penyakit (pre eklamsia, eklamsia, hipertensi), komplikasi pada kehamilan (perdarahan), usia yang terlalu muda maupun terlalu tua $(<20$ tahun dan $>35$ tahun), jumlah anak yang dilahirkan lebih dari 3, jarak kelahiran yang terlalu dekat atau pendek, riwayat BBLR sebelumnya, keadaan sosial ekonomi dan kebiasaan ibu (merokok, minum alkohol dan pecandu narkotika), faktor janin (Prematur, hidramion, kehamilan kembar/ ganda (gemeli), kelainan kromosom dan infeksi janin kronik), faktor plasenta dan faktor lingkungan (tempat tinggal di daratan tinggi, radiasi dan terpapar zat beracun) (Manuaba, 2009).

BBLR adalah salah satu hasil dari ibu hamil yang menderita energi kronis dan akan mempunyai status gizi buruk. BBLR berkaitan dengan tingginya angka kematian bayi dan 
balita, juga dapat berdampak serius pada kualitas generasi mendatang, yaitu akan memperlambat pertumbuhan dan perkembangan anak, serta berpengaruh pada penurunan kecerdasan (Maryati, 2011).

Pelayanan kesehatan pada ibu hamil tidak dapat dipisahkan dengan pelayanan persalinan, pelayanan kesehatan ibu nifas, dan pelayanan kesehatan bayi baru lahir. Kualitas pelayanan antenatal yang diberikan akan memengaruhi kesehatan ibu hamil dan janinnya, ibu bersalin, ibu nifas dan bayi baru lahir (Suryadi, 2010).

Berdasarkan penelitian lain yang dilakukan oleh Restiana, Arif pada tahun 2013 tentang Hubungan Umur dan Paritas dengan Kejadian BBLR di peroleh hasil terdapat hubungan yang signifikan antara umur dan paritas ibu terhadap kejadian berat badan lahir rendah BBLR (Restiani, 2013).

Penelitian oleh Merzalia di wilayah Belitung Timur menunjukkan bahwa ada hubungan yang bermakna antara usia kehamilan dengan kejadian berat badan lahir rendah. Dengan OR dapat dikatakan odds pada usia kehamilan yang preterm ( $<37$ minggu) berisiko melahirkan berat bayi lahir rendah 137,360 kali lebih besar di bandingkan dengan usia kehamilan yang aterm/post term (Merzalia, 2011).

Data dari Provinsi Aceh pada tahun 2007 terdapat 5,5\% ibu yang melahirkan bayi dengan BBLR. Kejadian ini mengalami peningkatan yang signifikan dari tahun sebelumnya yaitu pada tahun 2012 mencapai 7,6 \%, sedangkan pada tahun 2013 kejadian BBLR meningkat hingga 8,2\%. Kejadian ini lebih besar dari tahun sebelumnya (Dinas Kesehatan Aceh, 2014).

Berdasarkan data dinas Kesehatan Kabupaten Bireuen menunjukkan angka BBLR tahun 2014 berjumlah 198 kasus dari 9.005 jumlah kelahiran bayi (2,1\%) dan angka kematian bayi berjumlah 75 kasus dengan penyebab BBLR, Asfiksia, Sepsis dan kelainan kongenital. Pada tahun 2015 jumlah BBLR sebanyak 163 kasus dari 9.130 jumlah kelahiran bayi $(1,7 \%)$ dengan jumlah BBLR yang meninggal berjumlah 29 kasus dan BBLR hidup berjumlah 134 kasus. Pada tahun 2017 jumlah BBLR sebanyak 266 kasus dari 8.746 jumlah kelahiran bayi (3\%). Kasus BBLR tertinggi di Kabupaten Bireuen adalah di Kecamatan Peudada yaitu sebanyak 30 kasus dari 568 jumlah kelahiran hidup (5,2\%) (Dinas Kesehatan Kabupaten Bireuen, 2018).

Dari survey awal yang penulis lakukan di Wilayah kerja Puskesmas Peudada Kabupaten Bireuen dengan mewawancarai 5 ibu yang melahirkan bayi BBLR diperoleh data, 2 ibu hamil berusia diatas 35 tahun dan melahirkan anak lebih dari 3 orang, ibu jarang melakukan 
pemeriksaan kehamilan, selama hamil ibu juga tidak memperhatikan makanan yang bergizi untuk memenuhi kebutuhan bayinya dan satu diantaranya pernah mengalami kelahiran BBLR pada kehamilan sebelumnya. 2 Ibu hamil berusia diatas 35 tahun dan salah satu diantaranya melahirkan anak ke 5, ibu jarang melakukan pemeriksaan kehamilan dan tidak memperhatikan makanan yang dikonsumsinya. Ibu hamil berusia dibawah 20 tahun dan melahirkan anak pertama, ibu mengalami KEK pada saat hamil, ibu tidak memperhatikan makanan yang dikonsumsinya, tidak minum susu, hanya makan seadanya, bahkan ibu jarang melakukan pemeriksaan kehamilan. Dari data diatas dapat penulis simpulkan bahwa beberapa ibu yang melahirkan bayi BBLR, dikarenakan faktor usia yang terlalu muda ataupun terlalu tua, ibu sudah melahirkan anak lebih dari 3, ibu jarang melakukan pemeriksaan kehamilan, mempunyai riwayat nutrisi yang buruk, pengetahuan tentang gizi yang kurang, sehingga bayi yang dilahirkan BBLR, bahkan sampai sekarang kondisi bayi yang lahir dengan BBLR tidak mengalami penambahan berat badan yang signifikan.

Berdasarkan latar belakang diatas maka yang menjadi rumusan masalah dalam penelitian ini adalah apakah faktor umur ibu yang terlalu muda maupun terlalu tua (usia hamil berisiko), paritas, usia kehamilan yang kurang, KEK (kekurangan energi kronik) dan kurangnya kunjungan antenatal care pada masa kehamilan berhubungan dengan kejadian BBLR di wilayah kerja Puskesmas Peudada Kabupaten Bireuen tahun 2018 ?

Tujuan penelitian ini Untuk Mengetahui Faktor-faktor Yang Berhubungan Dengan Kejadian BBLR di Wilayah Kerja Puskesmas Peudada Kabupaten Bireuen Tahun 2018.

\section{METODE PENELITIAN}

Penelitian ini menggunakan survei analitik dengan pendekatan Case Control. Lokasi penelitian di lakukan di Wilayah Kerja Puskesmas Peudada Kabupaten Bireuen. dan waktu Penelitian ini dilakukan pada bulan Maret hingga Mei 2018. Populasi dalam penelitian ini adalah seluruh ibu yang melahirkan bayi BBLR dan bukan BBLR di wilayah kerja Puskesmas Peudada. Sampel dalam penelitian ini adalah keseluruhan dari populasi yang berjumlah 30 kasus dan 30 kontrol. Data dianalisis secara univariat dan bivariat dengan menggunakan uji chi-Square pada taraf kepercayaan $95 \%(\mathrm{p}<0,05)$.

\section{HASIL DAN PEMBAHASAN}

Analisis Bivariat digunakan untuk mengetahui hubungan antara variabel independen yaitu faktor risiko terhadap variabel dependen yaitu kejadian BBLR dengan menggunakan 


\section{e-ISSN : 2615-109X}

chi-square pada tingkat kemaknaan $95 \%$ atau nilai $(\alpha=0,05)$. Bila menunjukan nilai $\mathrm{p} \leq 0,05$ artinya ada hubungan bermakna atau signifikan. Selanjutnya juga mengetahui besar risiko (Odds ratio/ OR Nilai besarnya Odds Ratio ditentukan dengan rumus OR = a.d / b.c , dengan Confidence Interval ( CI ) $95 \%$.

Tabel 1. Hubungan Usia Hamil Berisiko, paritas, usia kehamilan, kekurangan energi kronik dan kunjungan ANC dengan kejadian BBLR di Wilayah Kerja Puskesmas Peudada tahun 2018

\begin{tabular}{|c|c|c|c|c|c|c|c|c|}
\hline \multirow{3}{*}{ Analisis Bivariat } & \multicolumn{4}{|c|}{ Kejadian BBLR } & \multirow{3}{*}{$\mathbf{N}$} & \multirow{3}{*}{ p-Value } & \multirow{3}{*}{$\mathbf{O R}$} & \multirow{3}{*}{ (CI95\%) } \\
\hline & \multicolumn{2}{|c|}{ Kasus } & \multicolumn{2}{|c|}{ Kontrol } & & & & \\
\hline & $\mathbf{n}$ & $\%$ & $\mathbf{n}$ & $\%$ & & & & \\
\hline \multicolumn{9}{|l|}{ Usia Hamil Berisiko } \\
\hline Risiko Tinggi $(<20 \&>35$ th $)$ & 17 & 28,3 & 6 & 10,0 & 23 & \multirow{2}{*}{0,008} & \multirow{2}{*}{5,231} & \multirow{2}{*}{$(1,657-16,515)$} \\
\hline Risiko Rendah (20-35 th) & 13 & 21,7 & 24 & 40,0 & 37 & & & \\
\hline \multicolumn{9}{|l|}{ Paritas } \\
\hline Risiko Tinggi ( $\geq 4$ orang) & 16 & 26,7 & 7 & 11,7 & 23 & \multirow{2}{*}{0,034} & \multirow{2}{*}{3,755} & \multirow{2}{*}{$(1,239-11,385)$} \\
\hline Risiko Rendah (< 4 orang) & 14 & 23,3 & 23 & 38,3 & 37 & & & \\
\hline \multicolumn{9}{|l|}{ Usia Kehamilan } \\
\hline Pre Aterm $(<37 \mathrm{minggu})$ & 11 & 18,3 & 2 & 3,3 & 13 & \multirow{2}{*}{0,012} & \multirow{2}{*}{8,105} & \multirow{2}{*}{$(1,612-40,766)$} \\
\hline Aterm $(\geq 37$ minggu $)$ & 19 & 31,7 & 28 & 46,7 & 47 & & & \\
\hline \multicolumn{9}{|l|}{ KEK } \\
\hline $\operatorname{KEK}(<23,5 \mathrm{~cm})$ & 16 & 26,7 & 5 & 8,3 & 21 & \multirow{2}{*}{0,007} & \multirow{2}{*}{5,714} & \multirow{2}{*}{$(1,724-18,944)$} \\
\hline $\operatorname{Normal}(\geq 23,5 \mathrm{~cm})$ & 14 & 23,3 & 25 & 41,7 & 39 & & & \\
\hline \multicolumn{9}{|l|}{ Kunjungan ANC } \\
\hline Tidak Lengkap (< 4 kali) & 17 & 28,3 & 8 & 13,3 & 25 & \multirow{2}{*}{0,036} & \multirow{2}{*}{3,596} & \multirow{2}{*}{$(1,216-10,638)$} \\
\hline Lengkap $(\geq 4$ kali $)$ & 13 & 21,7 & 22 & 36,7 & 35 & & & \\
\hline
\end{tabular}

Berdasarkan tabel diatas dapat dilihat bahwa hasil penelitian hubungan usia hamil berisiko dengan kejadian BBLR menunjukkan bahwa dari 23 responden yang memiliki usia risiko tinggi, yang mengalami kejadian BBLR sebanyak 17 orang $(28,3 \%)$ dan dari 37 responden yang memiliki usia risiko rendah (20-35 tahun), sebanyak 13 orang (21,7\%) yang mengalami kejadian BBLR. Berdasarkan hasil analisis uji statistik Chi-Square diperoleh nilai $p$-value $=0,008<\alpha 0,05$, yang berarti Ho ditolak dan Ha diterima maka dapat disimpulkan bahwa ada hubungan usia hamil berisiko dengan kejadian BBLR.

Berdasarkan analisis Odds Ratio (OR) diperoleh nilai Lower Limit- Upper Limit (LLUL) sebesar 5,231 $(95 \% \mathrm{CI})=(1,657-16,515)$, menunjukkan bahwa responden yang memiliki usia berisiko tinggi 5 kali cenderung mengalami kejadian BBLR.

Berdasarkan hasil penelitian hubungan paritas dengan kejadian BBLR menunjukkan bahwa dari 23 responden dengan paritas risiko tinggi ( $\geq 4$ orang), yang mengalami kejadian BBLR sebanyak 16 orang $(26,7 \%)$ dan dari 37 responden dengan paritas risiko rendah $(<4$ 
orang), sebanyak 14 orang (23,3\%) yang mengalami kejadian BBLR. Berdasarkan hasil analisis uji statistik Chi-Square diperoleh nilai $p$-value $=0,034<\alpha 0,05$, yang berarti Ho ditolak dan Ha diterima maka dapat disimpulkan bahwa ada hubungan paritas dengan kejadian BBLR.

Berdasarkan analisis Odds Ratio (OR) diperoleh nilai Lower Limit- Upper Limit (LLUL) sebesar 3,755 $(95 \% \mathrm{CI}=(1,239-11,385)$, menunjukkan bahwa responden dengan paritas risiko tinggi 3 kali cenderung mengalami kejadian BBLR.

Berdasarkan hasil penelitian hubungan usia kehamilan dengan kejadian BBLR menunjukkan bahwa dari 13 responden dengan usia kehamilan pre aterm $(<37$ minggu), yang mengalami kejadian BBLR sebanyak 11 orang $(18,3 \%)$ dan dari 47 responden dengan usia kehamilan aterm ( $\geq 37$ minggu), sebanyak 19 orang $(31,7 \%)$ yang mengalami kejadian BBLR. Berdasarkan hasil analisis uji statistik Chi-Square diperoleh nilai $p$-value $=0,012<\alpha$ 0,05, yang berarti Ho ditolak dan Ha diterima maka dapat disimpulkan bahwa ada hubungan usia kehamilan dengan kejadian BBLR.

Berdasarkan analisis Odds Ratio (OR) diperoleh nilai Lower Limit- Upper Limit (LLUL) sebesar 8,105 $(95 \% \mathrm{CI})=(1,612-40,766)$, menunjukkan bahwa responden dengan usia kehamilan aterm 8 kali cenderung mengalami kejadian BBLR.

Berdasarkan hasil penelitian hubungan kekurangan energi kronik dengan kejadian BBLR menunjukkan bahwa dari 21 responden yang kekurangan energi kronik, yang mengalami kejadian BBLR sebanyak 16 orang $(26,7 \%)$ dan dari 39 responden yang tidak kekurangan energi kronik, sebanyak 14 orang (23,3\%) yang mengalami kejadian BBLR. Berdasarkan hasil analisis uji statistik Chi-Square diperoleh nilai $p$-value $=0,007<\alpha 0,05$, yang berarti Ho ditolak dan Ha diterima maka dapat disimpulkan bahwa ada hubungan kekurangan energi kronik dengan kejadian BBLR.

Berdasarkan analisis Odds Ratio (OR) diperoleh nilai Lower Limit- Upper Limit (LLUL) sebesar 5,714 (95\% CI) $=(1,724-18,944)$, menunjukkan bahwa responden yang kekurangan energi kronik 5 kali cenderung mengalami kejadian BBLR.

Berdasarkan hasil penelitian hubungan kunjungan ANC dengan kejadian BBLR menunjukkan bahwa dari 25 responden yang melakukan kunjungan ANC secara tidak lengkap ( $<4$ kali), yang mengalami kejadian BBLR sebanyak 17 orang $(28,3 \%)$ dan dari 35 responden yang melakukan kunjungan ANC secara lengkap ( $\geq 4$ kali), sebanyak 13 orang $(21,7 \%)$ yang mengalami kejadian BBLR. Berdasarkan hasil analisis uji statistik Chi-Square 
diperoleh nilai $p$-value $=0,036<\alpha 0,05$, yang berarti Ho ditolak dan Ha diterima maka dapat disimpulkan bahwa ada hubungan kunjungan ANC dengan kejadian BBLR.

Berdasarkan analisis Odds Ratio (OR) diperoleh nilai Lower Limit- Upper Limit (LLUL) sebesar 3,596 (95\% CI) $=(1,216-10,638)$, menunjukkan bahwa responden yang melakukan kunjungan ANC tidak lengkap 3 kali cenderung mengalami kejadian BBLR.

\section{Pembahasan}

1. Kejadian BBLR di Wilayah Kerja Puskesmas Peudada

BBLR merupakan salah satu penyebab utama kematian neonatus. Di negara maju angka kematian pada bayi lahir relatif kecil, dan sebaliknya pada negara miskin atau negara terbelakang ditemukan angka kematian pada bayi lahir relatif tinggi sedang di negara berkembang angka kematian pada bayi lahir adalah lebih tinggi dari negara maju, dan lebih rendah dari negara miskin.

Kejadian BBLR di Kabupaten Bireuen menunjukkan angka BBLR tahun 2014 berjumlah 198 kasus dari 9.005 jumlah kelahiran bayi $(2,1 \%)$ dan angka kematian bayi berjumlah 75 kasus dengan penyebab BBLR, Asfiksia, Sepsis dan kelainan kongenital. Pada tahun 2015 jumlah BBLR sebanyak 163 kasus dari 9.130 jumlah kelahiran bayi $(1,7 \%)$ dengan jumlah BBLR yang meninggal berjumlah 29 kasus dan BBLR hidup berjumlah 134 kasus. Pada tahun 2016 jumlah BBLR sebanyak 266 kasus dari 8.746 jumlah kelahiran bayi (3\%). Kasus BBLR tertinggi di Kabupaten Bireuen adalah di Kecamatan Peudada yaitu sebanyak 30 kasus dari 568 jumlah kelahiran hidup (5,2\%). Berdasarkan hasil Riskesdas 2013 persentase kejadian BBLR sebesar 10,2\%, hasil SDKI tahun 2012 sebesar 15\% (Dinas Kesehatan Aceh, 2014).

Prevalensi BBLR diperkirakan 15\% dari seluruh kelahiran di dunia dan yang terjadi di negara berkembang. Asia tenggara merupakan insiden BBLR paling tinggi yaitu 27\% dan seluruh kelahiran bayi berat badan lahir rendah didunia prevalensi terendah di Eropa sebanyak 6,4\%. Sepuluh negara dengan prevalensi bayi berat lahir rendah (BBLR) terbesar yaitu Mauritania sebesar 34\%, Pakistan sebesar 32\%, India sebesar 28\%, Nauru sebesar 27\%, Niger sebesar 27\%, Haiti sebesar 25\%, Bangladesh sebesar 27\%, Philipines sebesar $21 \%$, Ethiopia sebesar $20 \%$ dan 5 negara dengan prevalensi bayi berat badan lahir rendah (BBLR) terendah yaitu Belarus, Montenegro, Turkmenistan dan Ukraine sebesar $4 \%$ dan Chuis sebesar 3\% (Kemenkes RI, 2014). 
2. Hubungan Usia Hamil Berisiko Dengan Kejadian BBLR di Wilayah Kerja Puskesmas Peudada

Penelitian ini menunjukkan sebanyak 28,3\% responden yang mengalami BBLR adalah usia $<20$ tahun dan > 35 tahun sebanyak 17 orang (28,3\%), sedangkan responden yang mengalami BBLR usia 20-35 tahun sebanyak 21,7\%. Berdasarkan hasil analisis uji statistik Chi-Square diperoleh nilai $p$-value $=0,008<\alpha 0,05$, yang berarti Ho ditolak dan Ha diterima maka dapat disimpulkan bahwa ada hubungan usia hamil berisiko dengan kejadian BBLR. Berdasarkan analisis Odds Ratio (OR) diperoleh nilai Lower Limit- Upper Limit (LL-UL) sebesar 5,231 (95\% CI) $=(1,657-16,515)$, menunjukkan bahwa responden yang memiliki usia berisiko tinggi 5 kali cenderung mengalami kejadian BBLR.

Kebanyakan ibu yang berusia > 35 tahun juga memiliki jumlah anak yang lebih dari 4, sehingga mereka merasa sudah mempunyai pengalaman dalam kehamilan, padahal sebagian besar dari mereka melahirkan bayi BBLR. Beberapa responden yang berusia $<20$ tahun merasa malu dengan kehamilannya karena usianya masih terlalu muda, sehingga responden tidak mengerti tentang tumbung kembang janin dan tidak melakukan pemeriksaan kehamilan yang menyebabkan terjadinya BBLR (Prawirohardjo, 2010).

Pada hasil penelitian di lapangan menunjukkan umur yang terlalu muda atau pun terlalu tua tidaklah baik bagi kehamilan seorang ibu apalagi ketika ibu harus melalui persalinan yang berulang-ulang. Berbagai risiko harus dihadapi ibu saat masa kehamilan maupun persalinan. Usia ibu yang masih sangat muda tidaklah baik bagi kesehatan dan keselamatan Ibu dan janin, apalagi di usia muda inilah emosi atau mental ibu belum matang. Hasil penelitian ini menunjukkan sebagian besar responden yang melahirkan bayi BBLR memiliki umur > 35 tahun (Pantiawati, 2010).

Usia ibu terlalu tua (lebih dari 35 tahun) maka akan sangat banyak resiko yang mungkin dihadapi ibu terkait dengan kondisi kesehatan reproduksinya. Ibu yang usianya terlalu tua, secara fisiologi mengalami penurunan fungsi organ tubuh seperti kelemahan otot-otot rahim dan kontraksinya. Hal inilah yang membuat organ tubuh lebih sensitif, apalagi jika terdapat benturan pada rahim ibu. Perdarahan adalah hal yang mungkin terjadi. Perdarahan yang terlalu sering tentu mengakibatkan kebutuhan nutrisi ibu dan bayi semakin meningkat. Namun jika perdarahan ini tidak teratasi dengan baik maka akan dapat menyebabkan terjadinya BBLR bahkan kematian janin (Prawirohardjo, 2010). 
Hasil penelitian sesuai dengan pendapat Manuaba yaitu usia di bawah 20 tahun dan lebih dari 35 tahun merupakan usia yang dianggap berisiko terhadap kelahiran prematur. Ibu yang hamil berusia kurang dari 20 tahun dapat berisiko pada kehamilan disebabkan karena belum matangnya alat reproduksi sehingga dapat merugikan kesehatan ibu maupun perkembangan janin. Ibu hamil yang berusia diatas 35 tahun, cenderung terjadi penyakit degeneratif seperti hipertensi dan diabetes mellitus, hipertensi bisa menyebabkan gawat janin sampai kematian karena kekurangan oksigenasi, sedangkan ibu hamil yang menderita diabetes mellitus dapat terjadi gangguan pertumbuhan janin dalam rahim, sehingga mengakibatkan BBLR (Pantiawati, 2010).

Hasil penelitian ini sesuai dengan penelitian yang dilakukan oleh Suryadi dengan judul Faktor risiko dan prognosis berat badan lahir rendah (BBLR) dan berat badan lahir sangat rendah (BBLRS) dan kejadian lahir mati di Kota Palembang tahun 2010 yang menemukan bahwa terdapat pengaruh antara umur terhadap kejadian berat badan lahir rendah dengan nilai $\mathrm{p}=0,0006$ (Suryadi, 2010). Hasil penelitian lain yang dilakukan oleh Restiana dengan judul pengaruh Umur dan Paritas dengan Kejadian Berat Badan Lahir Rendah (BBLR) menunjukkan bahwa ada hubungan yang signifikan antara umur dengan kejadian BBLR dengan nilai $\mathrm{p}=0,005$ (Restiani, 2013).

Selain terjadi pada usia < 20 tahun atau > 35 tahun, sebagian kecil kejadian BBLR juga terjadi pada usia 20-35 tahun, padahal usia tersebut merupakan usia risiko rendah terhadap kejadian BBLR. Hal ini disebabkan karena pada usia 20-35 tahun, beberapa ibu ada yang mengalami KEK. Oleh karena itu pada usia tersebut ibu juga bisa melahirkan BBLR.

Menurut peneliti, usia hamil berisiko berhubungan dengan kejadian BBLR disebabkan karena umur yang terlalu muda atau pun terlalu tua tidaklah baik bagi kehamilan seorang ibu apalagi ketika ibu harus melalui persalinan yang berulang-ulang. Ibu yang hamil berusia kurang dari 20 tahun dapat berisiko pada kehamilan disebabkan karena belum matangnya alat reproduksi sehingga dapat merugikan kesehatan ibu maupun perkembangan janin. Ibu hamil yang berusia diatas 35 tahun, cenderung terjadi penyakit degeneratif seperti hipertensi dan diabetes mellitus. Faktor usia memegang peranan penting terhadap derajat kesehatan dan kesejahteraan ibu hamil serta bayi, maka sebaiknya merencanakan kehamilan pada usia antara 20-35 tahun.

3. Hubungan Paritas Dengan Kejadian BBLR di Wilayah Kerja Puskesmas Peudada 
Penelitian ini menunjukkan sebanyak 26,7\% responden yang mengalami BBLR adalah responden dengan paritas $\geq 4$ orang, sedangkan responden yang mengalami BBLR dengan paritas $<4$ orang sebanyak 23,3\%. Berdasarkan hasil analisis uji statistik ChiSquare diperoleh nilai $p$-value $=0,034<\alpha 0,05$, yang berarti Ho ditolak dan Ha diterima maka dapat disimpulkan bahwa ada hubungan paritas dengan kejadian BBLR. Berdasarkan analisis Odds Ratio (OR) diperoleh nilai Lower Limit- Upper Limit (LL-UL) sebesar 3,755 $(95 \% \mathrm{CI})=(1,239-11,385)$, menunjukkan bahwa responden dengan paritas risiko tinggi 3 kali cenderung mengalami kejadian BBLR.

Hasil penelitian di lapangan menunjukkan ibu yang melahirkan anak $\geq 4$ orang tidaklah baik bagi kehamilan seorang ibu apalagi ketika ibu harus melalui persalinan yang berulang-ulang. Berbagai risiko harus dihadapi ibu saat masa kehamilan maupun persalinan. Paritas 2-3 merupakan paritas paling aman untuk hamil dan bersalin. Paritas tinggi (lebih dari 3 atau $\geq 4$ ) mempunyai angka kematian maternal lebih tinggi. Semakin tinggi paritas, maka semakin tinggi juga kematian maternal (Ridwan, 2014).

Ibu dengan paritas lebih dari 4 kali, risiko bayi untuk mengalami persalinan BBLR menjadi lebih tinggi. Hal ini disebabkan karena kehamilan yang berulang-ulang akan membuat uterus menjadi renggang, sehingga menyebabkan kelainan letak pada janin dan plasenta. Akhirnya akan berpengaruh buruk pada proses persalinan serta kemampuan untuk mengedan pada saat melahirkan sudah mulai berkurang sejalan dengan usia ibu itu sendiri (Ridwan, 2014).

Hasil penelitian ini sesuai dengan penelitian yang dilakukan oleh Restiani pada tahun 2013 tentang Hubungan Umur dan Paritas dengan Kejadian BBLR di peroleh hasil terdapat hubungan yang signifikan antara umur dan paritas ibu terhadap kejadian berat badan lahir rendah BBLR dengan nilai $\mathrm{p}=0,005$ (Restiani, 2013).

Selain terjadi pada paritas $\geq 4$ orang, sebagian kecil kejadian BBLR juga terjadi pada paritas $<4$ orang, padahal paritas tersebut merupakan risiko rendah terhadap kejadian BBLR. Hal ini disebabkan karena pada paritas $<4$ orang, beberapa ibu ada yang mengalami KEK, hidramnion dan plasenta previa. Oleh karena itu pada paritas $<4$ orang, kejadian BBLR bisa juga terjadi.

Menurut peneliti, paritas berhubungan dengan kejadian BBLR disebabkan karena Paritas tinggi (lebih dari 3 atau $\geq 4$ ) mempunyai angka kematian maternal lebih tinggi. Semakin tinggi paritas, maka semakin tinggi juga kematian maternal. Ibu yang pernah melahirkan anak empat kali atau lebih karena paritas yang terlalu tinggi akan 
mengakibatkan terganggunya uterus terutama dalam hal fungsi pembuluh darah. Hal ini akan mempengaruhi nutrisi ke janin pada kehamilan selanjutnya sehingga dapat melahirkan bayi dengan BBLR. Oleh sebab itu sebaiknya ibu melahirkan anak dibawah 4 orang.

4. Hubungan Usia Kehamilan Dengan Kejadian BBLR di Wilayah Kerja Puskesmas Peudada

Penelitian ini menunjukkan sebanyak 18,3\% responden yang mengalami BBLR adalah responden dengan usia kehamilan pre aterm $(<37$ minggu), sedangkan responden yang mengalami BBLR dengan usia kehamilan aterm ( $\geq 37$ minggu) sebanyak 31,7\%. Berdasarkan hasil analisis uji statistik Chi-Square diperoleh nilai $p$ - value $=0,012<\alpha$ 0,05, yang berarti Ho ditolak dan Ha diterima maka dapat disimpulkan bahwa ada hubungan usia kehamilan dengan kejadian BBLR. Berdasarkan analisis Odds Ratio (OR) diperoleh nilai Lower Limit- Upper Limit (LL-UL) sebesar 8,105 (95\% CI) $=(1,612$ 40,766), menunjukkan bahwa responden dengan usia kehamilan aterm 8 kali cenderung mengalami kejadian BBLR.

Hasil penelitian dilapangan menunjukkan bahwa usia kehamilan $<37$ minggu maupun $\geq 37$ minggu dapat menyebabkan BBLR. Hasil uji statistik diperoleh ada perbedaan rata-rata usia kehamilan pada kelompok BBLR maupun tidak BBLR. Hal ini menunjukkan bahwa salah satu penyebab terjadinya BBLR adalah usia kehamilan < 37 minggu, dan selain itu BBLR juga terjadi pada usia kehamilan $\geq 37$ minggu. Hal ini disebabkan antara lain karena pre eklamsi, kekurangan energi kronik (KEK), riwayat sesak, insufisiensi plasenta, anemia sedang, plasenta previa, hidramnion dan ketuban pecah dini sehingga janin dapat lahir pada usia kehamilan $\geq 37$ minggu.

Hasil penelitian ini sejalan dengan penelitian yang dilakukan oleh Merzalia dengan judul Determinan kejadian berat badan lahir rendah (BBLR) di Kabupaten Belitung Timur Provinsi Kepulauan Bangka Belitung tahun 2012 menunjukkan bahwa ada hubungan yang bermakna antara usia kehamilan dengan kejadian berat badan lahir rendah dengan nilai $\mathrm{p}=0,000$.(11).Namun perbedaannya adalah penelitian Merzalia menunjukkan bahwa usia kehamilan < 37 minggu yang banyak terjadi BBLR. Dan Hasil penelitian lain yang dilakukan oleh Rahmi dengan judul Faktor-faktor Yang Berhubungan Dengan Kejadian Bayi Berat Lahir Rendah di RSIA Pertiwi Makassar Tahun menunjukkan bahwa ada hubungan yang signifikan antara usia kehamilan dengan kejadian BBLR dengan nilai $\mathrm{p}=$ 0,000 (Rahmi, 2013). 
Dan hasil penelitian lain tidak sejalan dengan penelitian yang dilakukan Leonardo (2011) dengan judul Perbedaan Luaran Janin Pada Persalinan Preterm Usia Kehamilan 34 36 Minggu Dengan Atau Tanpa Ketuban Pecah Dini yang menunjukkan ada hubungan antara usia kehamilan dengan ibu dengan kejadian BBLR yang menyatakan wanita dengan persalinan preterm umur 34-36 minggu atau kurang dari 37 minggu dapat melahirkan BBLR (Leonardo, 2011).

Menurut peneliti, usia kehamilan berhubungan dengan kejadian BBLR disebabkan karena kehamilan aterm yang di akibatkan oleh beberapa faktor seperti pre eklamsi, kekurangan energi kronik (KEK), riwayat sesak, insufisiensi plasenta, anemia sedang, plasenta previa, hidramnion dan ketuban pecah dini. Oleh karena faktor tersebut maka janin terlahir dalam kondisi BBLR walaupun usia kehamilannya aterm.

5. Hubungan Kekurangan Energi Kronik Dengan Kejadian BBLR di Wilayah Kerja Puskesmas Peudada

Penelitian ini menunjukkan sebanyak 26,7\% responden yang mengalami BBLR adalah responden yang kekurangan energi kronik sedangkan responden yang mengalami BBLR dan tidak kekurangan energi kronik sebanyak 23,3\%. Berdasarkan hasil analisis uji statistik Chi-Square diperoleh nilai $p$-value $=0,007<\alpha 0,05$, yang berarti Ho ditolak dan Ha diterima maka dapat disimpulkan bahwa ada hubungan kekurangan energi kronik dengan kejadian BBLR. Berdasarkan analisis Odds Ratio (OR) diperoleh nilai Lower Limit- Upper Limit (LL-UL) sebesar 5,714 (95\% CI) = (1,724-18,944), menunjukkan bahwa responden yang kekurangan energi kronik 5 kali cenderung mengalami kejadian BBLR.

Hasil penelitian dilapangan menunjukkan sebanyak 26,7\% ibu yang kekurangan energi kronik mengalami kejadian BBLR. Kekurangan Energi Kronis (KEK) merupakan suatu keadaan dimana ibu menderita keadaan kekurangan makanan yang berlangsung menahun (kronis) yang mengakibatkan timbulnya gangguan kesehatan pada ibu. KEK merupakan gambaran status gizi ibu di masa lalu, kekurangan gizi kronis pada masa anakanak baik disertai sakit yang berulang, akan menyebabkan bentuk tubuh yang kuntet (stunting) atau kurus (wasting) pada saat dewasa. Ibu yang memiliki postur tubuh seperti ini berisiko mengalami gangguan pada masa kehamilan dan melahirkan bayi BBLR (Soetjiningsih, 2009).

Kenaikan berat badan ibu, selama kehamilan trimester 1 mempunyai peranan yang sangat penting, karena periode ini janin dan plasenta dibentuk. Kegagalan kenaikan berat 
badan ibu pada trisemester 1 dan 2 akan meningkatkan bayi BBLR. Hal ini disebabkan adanya KEK yang mengakibatkan ukuran plasenta kecil dan kurangnya suplai zat-zat makanan ke janin. Bayi BBLR mempunyai risiko kematian lebih tinggi dari pada bayi cukup bulan. Kekurangan zat gizi pada ibu lebih cenderung mengakibatkan BBLR atau kelainan yang bersifat umum dari pada menyebabkan kelainan anatomik yang spesifik. Kekurangan zat gizi pada ibu yang lama dan berkelanjutan selama masa kehamilan akan berakibat lebih buruk pada janin dari pada malnutrisi akut (Soetjiningsih, 2009).

Hasil penelitian ini sejalan dengan penelitian yang dilakukan oleh Saraswati dengan judul risiko ibu hamil kurang energi kronis (KEK) dan anemia untuk melahirkan bayi dengan berat badan lahir rendah (BBLR) yang menunjukkan bahwa ada hubungan kurang energi kronis dengan kejadian BBLR dengan nilai $\mathrm{p}=0,014$ (Saraswati, 2010). Penelitian ini juga sesuai dengan penelitian yang dilakukan oleh Merzalia dengan judul Determinan kejadian berat badan lahir rendah (BBLR) di Kabupaten Belitung Timur Provinsi Kepulauan Bangka Belitung yang menemukan bahwa ada hubungan antara KEK dengan kejadian BBLR dengan nilai $\mathrm{p}=0,000$ dan $\mathrm{OR}=7,018$, yang berarti ibu hamil yang mengalami KEK berisiko melahirkan bayi dengan berat badan lahir rendah 7 kali lebih besar dibandingkan dengan ibu yang tidak KEK (Merzalia, 2011).

Ibu hamil yang menderita KEK mempunyai risiko kesakitan yang lebih besar terutama pada trimester III kehamilan dibandingkan dengan ibu hamil normal. Ibu hamil yang menderita KEK dapat mengakibatkan ukuran plasenta menjadi lebih kecil sehingga transfer oksigen dan nutrient ke janin jadi berkurang. Dampaknya adalah ibu tersebut akan melahirkan bayi kecil atau BBLR. Untuk mencegah risiko KEK pada ibu hamil, diharapkan semua wanita usia subur, sebelum hamil sudah mempunyai gizi yang baik (LILA $\geq 23,5 \mathrm{Cm}$ ). Apabila hal ini belum tercapai sebaiknya kehamilan ditunda dulu agar tidak melahirkan bayi BBLR dan risiko lainnya. Ibu-ibu hamil yang sudah KEK disarankan harus mau meningkatkan asupan gizinya dengan makanan yang tinggi kalori dan tinggi protein dan mendapatkan makanan tambahan dari pihak puskesmas secara gratis bagi yang tidak mampu atau miskin dan kepada Pemerintah diharapkan untuk melakukan kerja sama dengan dinas terkait seperti dinas pertanian dalam hal meningkatkan gizi masyarakat.

Menurut peneliti, kekurangan energi kronik berhubungan dengan kejadian BBLR disebabkan karena adanya kekurangan energi kronik (KEK) yang mengakibatkan ukuran plasenta kecil dan kurangnya suplai zat-zat makanan ke janin sehingga janin yang akan 
dilahirkan mengalami BBLR. Kekurangan zat gizi pada ibu yang lama dan berkelanjutan selama masa kehamilan akan berakibat lebih buruk pada janin.

6. Hubungan Kunjungan ANC dengan Kejadian BBLR di Wilayah Kerja Puskesmas Peudada

Penelitian ini menunjukkan sebanyak 28,3\% responden yang mengalami BBLR adalah responden yang tidak lengkap melakukan kunjungan ANC $(<4$ kali $)$, sedangkan responden yang mengalami BBLR dan melakukan kunjungan ANC secara lengkap $(\geq 4$ kali) sebanyak 21,7\%. Berdasarkan hasil analisis uji statistik Chi-Square diperoleh nilai $p$ value $=0,036<\alpha 0,05$, yang berarti Ho ditolak dan Ha diterima maka dapat disimpulkan bahwa ada hubungan kunjungan ANC dengan kejadian BBLR. Berdasarkan analisis Odds Ratio (OR) diperoleh nilai Lower Limit- Upper Limit (LL-UL) sebesar 3,596 (95\% CI) = (1,216-10,638), menunjukkan bahwa responden yang melakukan kunjungan ANC tidak lengkap 3 kali cenderung mengalami kejadian BBLR.

Kunjungan ANC yang dimaksud yaitu jumlah pemeriksaan kehamilan ibu pada trimester I, II dan III lengkap dan sesuai masa kunjungan. Pemeriksaan yang rutin merupakan salah satu cara mencegah terjadinya BBLR karena dapat memantau tumbuh kembang dan berat badan janin tersebut serta dapat menurunkan angka kecacatan dan kematian ibu maupun janin. Pemeriksaan kehamilan yang tidak lengkap $(<4$ kali) dapat menyebabkan BBLR, kurangnya pemahaman dan pengetahuan ibu hamil tentang pentingnya pemeriksaan kehamilan pada saat hamil agar dapat mendapatkan diagnosa (Manuaba, 2009).

Hasil penelitian dilapangan menunjukkan sebagian besar ibu yang melakukan kunjungan ANC secara tidak lengkap ( $<4$ kali) mengalami kejadian BBLR. Hal ini disebabkan karena kurangnya pengetahuan ibu tentang apa yang terjadi dalam tumbuh kembang janin dalam rahim. Pemeriksaan kehamilan sangat penting untuk memantau kemajuan dan memastikan kesehatan ibu dan tumbuh kembang anak, meningkatkan dan mempertahankan kesehatan fisik dan mental, mengenali secara dini adanya ketidaknormalan atau komplikasi, mempersiapkan persalinan cukup bulan dan mempersiapkan ibu agar masa nifas berjalan normal (Manuaba, 2009). 
WHO membuat kebijakan program kunjungan dimana Frekwensi pemeriksaan antenatal sebagai berikut : Minimal 1 kali pada trimester I yaitu pada awal kehamilan-28 minggu, Minimal 1 kali pada trimester II yaitu pada usia kehamilan 28 minggu-36 minggu dan Minimal 2 kali pada trimester III yaitu pada usia kehamilan 36 minggu sampai lahir (Manuaba, 2009).

Hasil penelitian ini sesuai dengan penelitian yang dilakukan oleh S.D Singh (2011) yang menunjukkan ada hubungan antara kunjungan ANC dengan kejadian BBLR dan menyatakan kunjungan < 4 kali menyebabkan terjadinya BBLR (Singh, 2011). Dan hasil penelitian ini juga sesuai dengan penelitian yang dilakukan oleh Rini yang menyatakan bahwa terdapat hubungan yang signifikan antara jumlah kunjungan antenatal dengan kejadian BBLR. Jumlah antenatal risiko tinggi ( $<4$ kali) meningkatkan terjadinya BBLR sebesar 52,1 kali lebih besar daripada jumlah antenatal risiko rendah ( $\geq 4$ kali) (Rini, 2012).

Menurut peneliti, kunjungan ANC berhubungan dengan kejadian BBLR disebabkan karena melalui Pemeriksaan yang lengkap merupakan salah satu cara mencegah terjadinya BBLR dapat mendeteksi sedini mungkin jika ada kelainan pada ibu dan janin selama kehamilan sedangkan pemeriksaan kehamilan yang tidak lengkap dapat menyebabkan BBLR karena kurangnya pemahaman dan pengetahuan ibu hamil sehingga tidak dapat dideteksi secara dini kelainan pada kehamilan sehingga akan terjadi BBLR. Pelayanan kesehatan pada ibu hamil tidak dapat dipisahkan dengan pelayanan persalinan, pelayanan kesehatan nifas dan pelayanan kesehatan bayi baru lahir.

\section{KESIMPULAN}

Kesimpulan penelitian ini ada hubungan Faktor usia hamil berisiko, paritas, usia kehamilan, kekurangan energi kronik dan kunjungan antenatal care dengan kejadian BBLR di Wilayah Kerja Puskesmas Peudada Kabupaten Bireuen Tahun 2018.

\section{SARAN}

Disarankan Kepada tenaga kesehatan dan Puskesmas Peudada, untuk memberikan pelayanan, pendidikan, penyuluhan dan menggalakkan program untuk mengatasi masalah yang terkait dengan kejadian BBLR.

\section{DAFTAR PUSTAKA}

Depkes RI. Kumpulan Buku Acuan Kesehatan Bayi Baru Lahir. Jakarta: Departemen 
Kesehatan Republik Indonesia; 2011.

Dinas Kesehatan Aceh. Profil Kesehatan Indonesia Tahun 2013. Jakarta: Kementrian Kesehatan Republik Indonesia; 2014.

Dinas Kesehatan Kabupaten Bireuen. Jumlah Kejadian BBLR Tahun 2014-2018. Bireuen; 2018.

Kementrian Kesehatan RI. Buku Ajar Kesehatan ibu Dan Anak. Jakarta Selata: Pusat Pendidikan dan Pelatihan tenaga Kesehatan; 2015.

Kemenkes RI. Riset kesehatan dasar tahun 2013. Jakarta: Kementrian Kesehatan Republik Indonesia; 2014.

Leonardo. Perbedaan Luaran Janin Pada Persalinan Preterm Usia Kehamilan 34-36 Minggu Dengan Atau Tanpa Ketuban Pecah Dini. Jurnal Kesehatan: Fakultas Kedokteran Universitas Diponogoro; 2011.

Manuaba. Ilmu Kebidanan Penyakit Kandungan dan Keluarga Berencana Untuk Pendidikan Bidan. Jakarta: Penerbit Buku Kedokteran EGC; 2009.

Maryati, D. Buku Ajar Neonatus, Bayi, Balita. Jakarta: Trans Info Media; 2011.

Merzalia N. Determinan kejadian berat badan lahir rendah (BBLR) di Kabupaten Belitung Timur Provinsi Kepulauan Bangka Belitung. Fakultas Kesehatan Masyarakat Depok; 2011.

Pantiawati, I. Bayi dengan BBLR. Yogyakarta: Nuha Medika; 2010.

Prawirohardjo, S. Ilmu Kebidanan. Jakarta; PT Bina Pustaka Sarwono Prawirohardjo; 2010.

Proverawati, A. BBLR (Berat Badan Lahir Rendah). Yogyakarta: Nuha Medika; 2010.

Rahmi. Faktor-faktor Yang Berhubungan Dengan Kejadian BBLR Di RSIA Pertiwi Makassar. Makassar; 2013.

Restiani, dkk. Hubungan Umur dan Paritas dengan Kejadian Berat Badan Lahir Rendah (BBLR). E-Jurnal Obstretika Vol 1; 2013.

Ridwan. Determinan Kesehatan Ibu Dan Bayi. Jakarta: Trans Info Media; 2014.

Rini, SS. Faktor risiko kejadian berat badan lahir rendah di wilayah kerja Unit pelayanan Terpadu Kesmas Ganyar II. Bali: Fakultas Kedokteran Universitas Udayana; 2012.

Salmawati. Hubungan Antenatal Care Dengan Kejadian BBLR Tahun 2009-2010 Di Kecamatan Lalan Kabupaten Musi Banyu Asin Sumatera Selatan. Depok: FKM UI; 2011.

Saraswati E. Risiko ibu hamil kurang energi kronik (KEK) dan anemia untuk melahirkan bayi dengan berat badan lahir rendah (BBLR). Jurnal PGM; Volume 21. 2010.

SDKI. Survey demografi Kesehatan Indonesia. Jakarta: Kementrian Kesehatan Republik Indonesia; 2014.

SDKI. Survei Demografi dan Kesehatan Indonesia. Laporan Pendahuluan SDKI. Jakarta : Kementrian Kesehatan Republik Indonesia; 2012.

Singh S.D. Incidence And Risk Factors Of Low Birth Weight Babies Born In Dhulikhel 
Hospital. Jurnal Kesehatan Masyarakat: Universitas Kathmandu, Nepal; 2011.

Soetjiningsih. Tumbuh Kembang Anak. Jakarta: EGC; 2009.

Suryadi RM. Faktor risiko dan prognosis berat badan lahir rendah (BBLR) dan berat badan lahir sangat rendah (BBLRS) dan kejadian lahir mati di Kota Palembang. Jurnal Kedokteran Kesehatan, ISSN: 0-853-1773; 2010. 